\title{
Mountain lakes, pristine or polluted?
}

\author{
Richard W. Battarbee \\ Environmental Change Research Centre, University College London, London, WC1H 0AP. \\ r.battarbee@geog.ucl.ac.uk
}

\begin{abstract}
This paper presents conclusions from a number of collaborative research projects on remote mountain lakes across Europe funded by the European Union. In particular it describes how the sediment records of key research sites can be used to identify the timing, extent and impact of air pollution on lakes by acid deposition, trace metals and trace organic compounds. It also describes recent work that aims to assess the impact of 20th century climate change on these lakes and whether the changes observed are the result of natural climate variability or the enhanced greenhouse effect.
\end{abstract}

Keywords: mountain lake, lake sediment, atmospheric pollutant, climatic change

\section{RESUMEN}

Este artículo presenta las conclusiones de varios proyectos de colaboración en el estudio de lagos de montaña remotos distribuidos por Europa y financiados por la Unión Europea. De forma particular describe como el registro sedimentario de varias localidades clave puede ser usado para identificar el cambio temporal, la intensidad y el impacto de la contaminación atmosférica en lagos por deposición ácida, metales traza y compuestos orgánicos trazadores. Este trabajo también describe el trabajo reciente para ayudar a valorar el impacto del cambio climático del siglo XX sobre estos lagos y si los cambios observados son el resultado de la variabilidad climática natural o el aumento del efecto invernadero.

Palabras clave: lagos de montaña, sedimento lacustres, contaminación atmosférica, cambio climático.

\section{INTRODUCTION}

Remote mountain lakes, whether found in high altitudes or high latitudes, usually appear to be in pristine condition. In particular those lakes that are situated above or beyond the tree-line are rarely disturbed by agricultural or forestry practices and few if any people inhabit their catchments. However, recent research funded by the European Union indicates that even the most remote lakes in Europe contain atmospherically transported pollutants and evidence is growing that climate change is beginning to have a significant impact.

To identify the impacts of atmospheric pollution and climate change independently of other stresses sites are selected that are above (altitude) or beyond (latitude) the local natural timberline, and have catchments undisturbed by human activity. In addition, and although mountain regions in Europe are not uniformly distributed, sites are also selected so that they can be arranged along environmental gradients, principally air pollution and climate gradients, across Europe. Figure 1 shows the principal sites.

\section{SITES}

Although all sites are relatively small, oligotrophic $\left(\mathrm{TP}<10 \mu \mathrm{g} \mathrm{1}^{-1}\right)$ headwater lakes produ- 


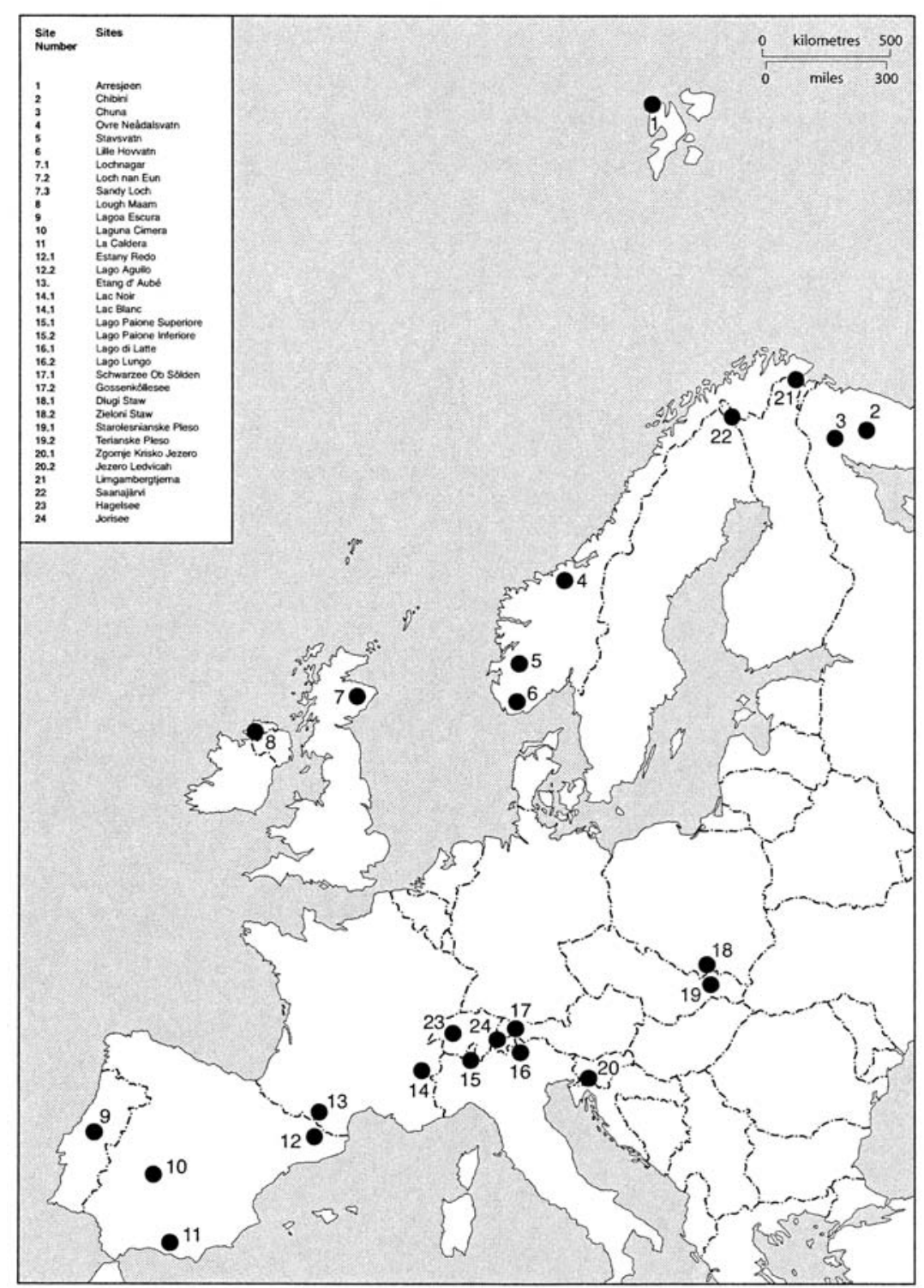

Figure 1. Location of mountain lake sites included in the European projects, AL:PE and MOLAR (from Battarbee et al., 2001). Localización de los lagos de montaña incluidos en los proyectos europeos, AL:PE y MOLAR (tomado de Battarbee et al., 2001).

ced by glacier erosion during the last glacial period they differ considerably in their depth $(2-73 \mathrm{~m})$, in their $\mathrm{pH}(4.5-8.0)$ and in the length of winter ice-cover (up to 8 months). Almost all the lakes have good relatively organic (5-20\%) sediment records containing an abundance of microfossils, especially diatoms, cladocera and chironomids. Accumulation rates are low (less than $1 \mathrm{~mm}$ per year) and sometimes much less, but this is to some extent compensated for by the relatively low degree of bioturbation from benthic invertebrates. With fine interval sampling (e.g. $2 \mathrm{~mm}$ ), therefore, it is usually possible to take samples to give a good time resolution, decadal or better, and sufficient to show clear trends in pollution. Figure 2 shows a range of accumulation rates from 7 of the sites shown in Figure 1. 


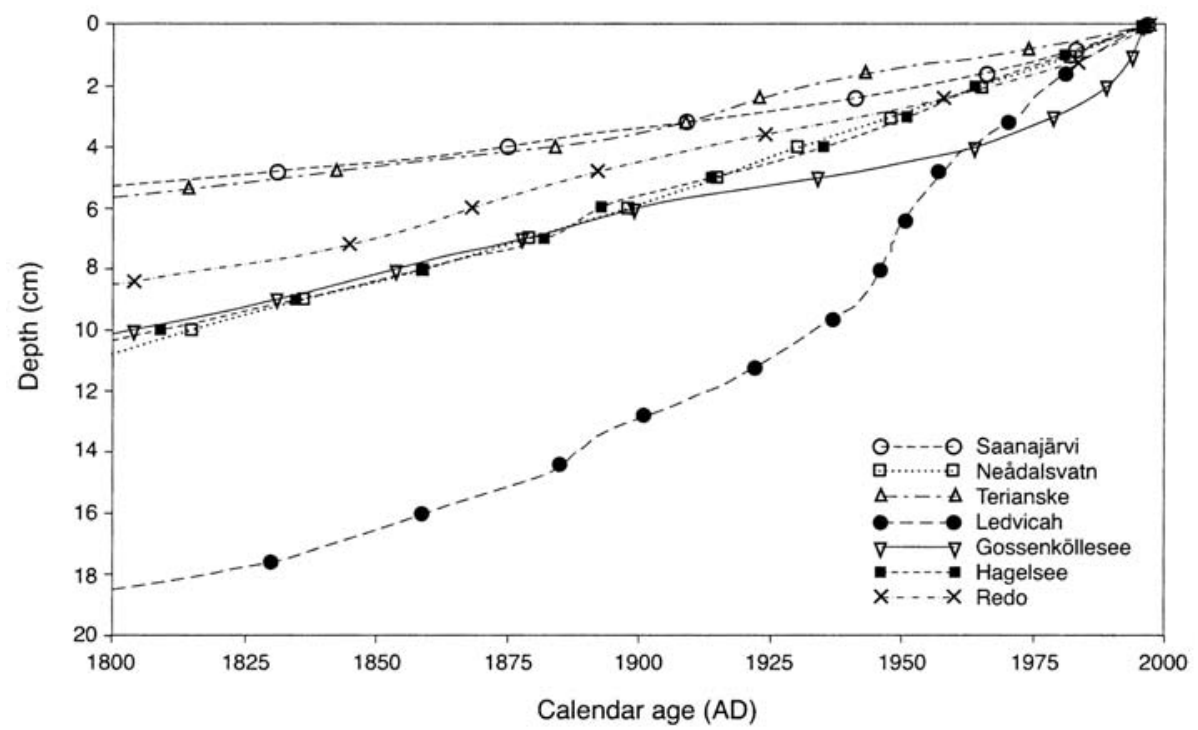

Figure 2. Sediment age-depth relationships based on ${ }^{210} \mathrm{~Pb}$ dating for seven mountain lakes in Europe (from Battarbee et al., 2002). Relación edad del sedimento-profundidad basada en la datación con ${ }^{210} \mathrm{~Pb}$ en siete lagos de montaña de Europa (tomado de Battarbee et al., 2002).

\section{ACID DEPOSITION}

The combustion of coal and oil gives rise to the emission into the atmosphere of sulphur and nitrogen gases and fly ash particles. Evidence for the contamination of mountain lakes by these products can be demonstrated from the high concentration of non-marine sulphate and nitrate in the water column (Battarbee et al., 2001) and the presence of fly ash particles, especially spheroidal carbonaceous particles (SCP) in the sediment (Rose et al., 2002). The spatial variation in concentration of these substances is in good agreement with the distribution of industrialised regions within Europe and the temporal variation in the concentration of SCPs measured in sediment cores reflects the progressive industrialisation of Europe from the nineteenth century to the present day.

Whilst many mountain lakes in Europe remain un-acidified either because they have adequate natural alkalinity to neutralise the acidity or because they occur in regions of low acid deposition, lakes in high acid deposition that have low natural alkalinity have been acidified. This is reflected most clearly by changes in the composition of diatom assemblages preserved in recent lake sediments. For example, analysis of a sediment core from Lochnagar, a low alkalinity mountain lake in Scotland (Fig. 3) shows a rapid decrease in Achnanthes minutissima and A. scotica in the late nineteenth century followed by a strong increase in Eunotia incisa, Aulacoseira distans var. nivalis, and Achnanthes marginulata in the early twentieth century representing a decrease in lake water $\mathrm{pH}$ from 5.7 to 5.0. In contrast analysis of a core from Laguna Cimera (Toro, unpublished), a mountain lake in the Gredos Mts of Central Spain, a site as equally sensitive to acid deposition as Lochnagar, but in a region of very low acid deposition, shows little or no change in the composition of the diatom assemblages over this time period, and indicates that this region of Spain suffers little from acid rain. 

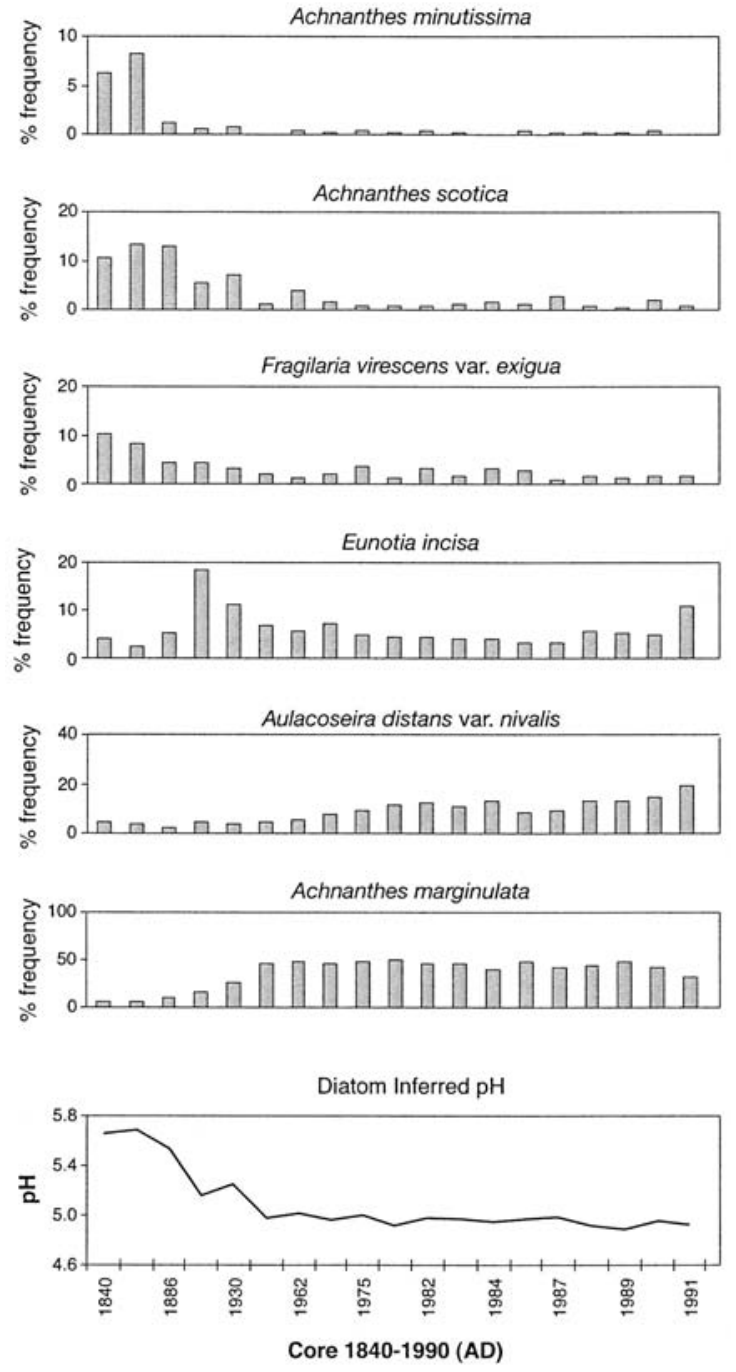

Figure 3. Diatom assemblage changes over approximately the last 150 years for Lochnagar, Scotland (re-drawn from Jones et al., 1993). Cambios en la comunidad de diatomeas durante los últimos 150 años aproximadamente en Lochnagart, Scotland (adaptado de Jones et al., 2003).

\section{TRACE METALS AND ORGANIC COMPOUNDS}

In addition to acidity and fly ash contamination mountain lakes are also contaminated by toxic metals and organic compounds. The increases that have taken place over the last century or so can also be clearly observed from analyses of sediment cores. Figure 4 shows changes in the

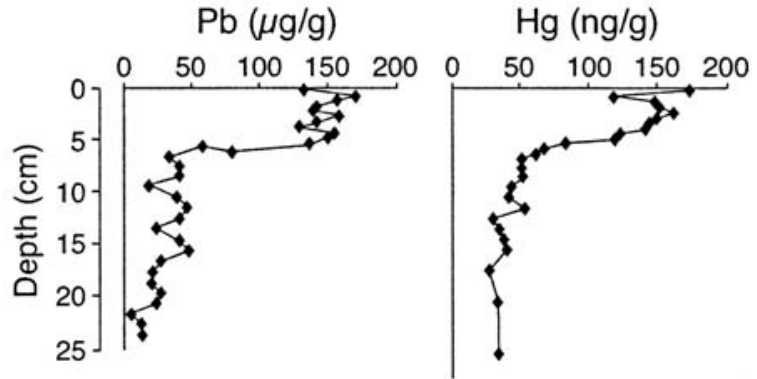

Figure 4. Lead and mercury concentration changes over the last 150 years from a Lochnagar sediment core (NAG14) (from Yang et al., 2002). Cambios en las concentraciones de plomo y mercurio durante los últimos 150 años en un core de sedimento de Lochnagar (NAG14) (tomado de Yang et al., 2002).

concentration of the trace metals $\mathrm{Pb}$ and $\mathrm{Hg}$ from Lochnagar sediments (Yang et al., 2002). The pattern of change through time is very similar to the pattern for the acidification of the lake indicating that these metals and the pollutants responsible for acidification ( $\mathrm{S}$ and $\mathrm{N}$ compounds) have a common origin, generally from industrial sources and more specifically from the combustion of fossil fuel. Similar trends are seen elsewhere in most regions of Europe even those remote from industrial source regions. Whilst there has been significant reductions in the emissions of toxic metals over recent decades these substances are persistent and high concentrations can still be found in soils and sediments in situations where they can be ingested by invertebrates and other animals and thereby remain in aquatic food chains. Indeed fish from the most remote sites in Europe, especially the high alpine zone carry substantial burdens of toxic metals in their tissues (Rognerud et al., 2002).

For organic compounds derived from fossil fuel combustion, for example the polycyclic aromatic hydrocarbons (PAHs), trends in sediment cores often follow those for fly-ash particles, illustrating their common source. However, pesticide residues, such as DDE, follow an independent trends reflecting their different source and their mainly post-World War II usage. Indeed the presence of some persistent organic pollutants 
(POPs), such as toxaphene, in the Scottish mountains indicates long-range transport from North America, as this substance has not been used in Western Europe (Rose et al., 2001). For some POPs there is evidence that concentrations increase with altitude (Fig. 5) as these substances become progressively redistributed to colder and more remote regions by volatilization and cold trapping processes (Grimalt et al., 2001) and contaminate lakes that are distant from the production and use of the compounds. The accumulation pattern of these compounds depends on local climatic conditions whereas their atmospheric fallout is quite uniform and seasonally dependent. Temperature is also the main factor controlling the deposition fluxes of lower molecular weight PAHs but particle deposition and wet precipitation determine the atmospheric deposition fluxes of the higher molecular weight PAH homologues. Some of the highest concentrations in both metals and POPs are found in Svalbard, one of the most remote regions of the world, where levels of $\mathrm{Hg}$, and a number of PCB congeners are double those at other sites as a result of food chain biomagnification. Rognerud et al., (2002) have shown that these higher values are the result of a progressive shift to cannibalism in the diet of arctic char between the ages of 11 and 20.

\section{CLIMATE CHANGE}

Most early studies of environmental change in mountain regions assumed that climate, although variable, imposed a relatively constant influence over the long term on aquatic ecology. It is now becoming clear, however, that this is not the case, and that climate change is exerting an additional stress on lakes in several regions. The climatic impact on mountain lakes is driven mainly through changes in temperature, precipitation and wind regimes that affect snow and ice cover, catchment hydrology, and water column stratification and mixing. These, in turn, control many chemical and biological processes such as primary production, nutrient cycling, hypolimnetic $\mathrm{O}_{2}$ consumption, alkalinity generation and water column $\mathrm{pH}$, and have a strong influence directly on habitat characteristics and distribution, and on biological life-cycles.
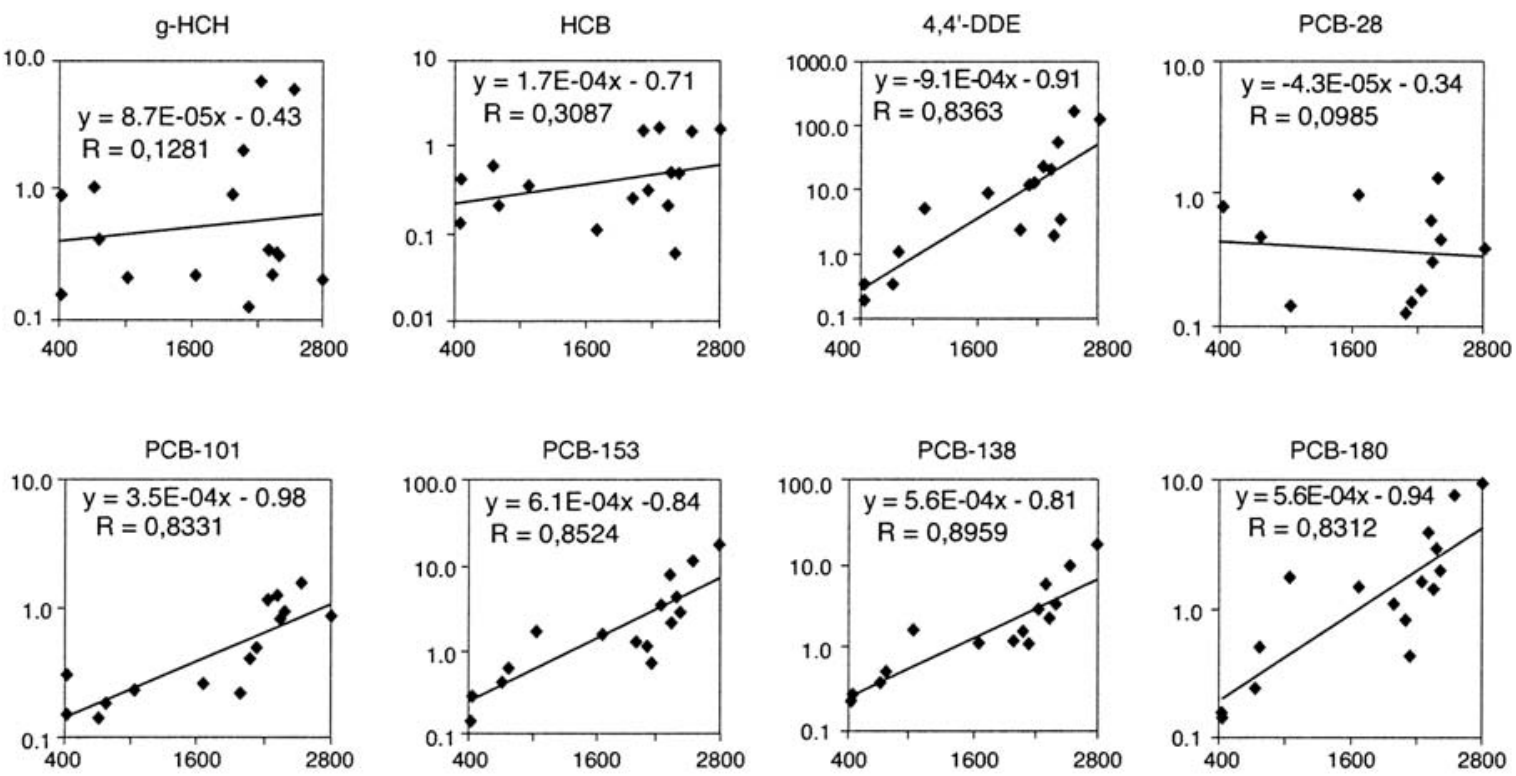

Figure 5. Organochlorine concentrations in fish in lakes at different altitudes in Europe (from Grimalt et al., 2001). Concentraciones de organoclorados en peces de lagos situados a diferentes altitudes en Europa (tomado de Grimalt et al., 2001). 
Instrumental temperature reconstructions for the last 200 years by Agustí-Panareda \& Thompson (2002) show that decadal-scale fluctuations in mean annual temperature with an amplitude of up to $2^{\circ} \mathrm{C}$ have taken place at mountain lake sites and that the most intense warming has taken place over the last few decades. These changes are sufficient to cause ecologically important changes in lake-catchment behaviour, and palaeolimnological studies covering this time period provide strong evidence for such changes, specifically through their controlling influence on lake acidity and lake productivity. For acidity Psenner \& Schmidt (1992) have shown from diatom analysis of recent sediments in the Austrian Alps that interannual and decadal fluctuations in $\mathrm{pH}$ are closely related to changes in mean annual air temperature. Temperature plays an important role in driving the generation of alkalinity in lakes and lake catchments, and that for naturally low alkalinity lakes relatively small changes in alkalinity can lead to significant shifts in lake water $\mathrm{pH}$, that in turn have a marked impact on the composition of diatom communities.

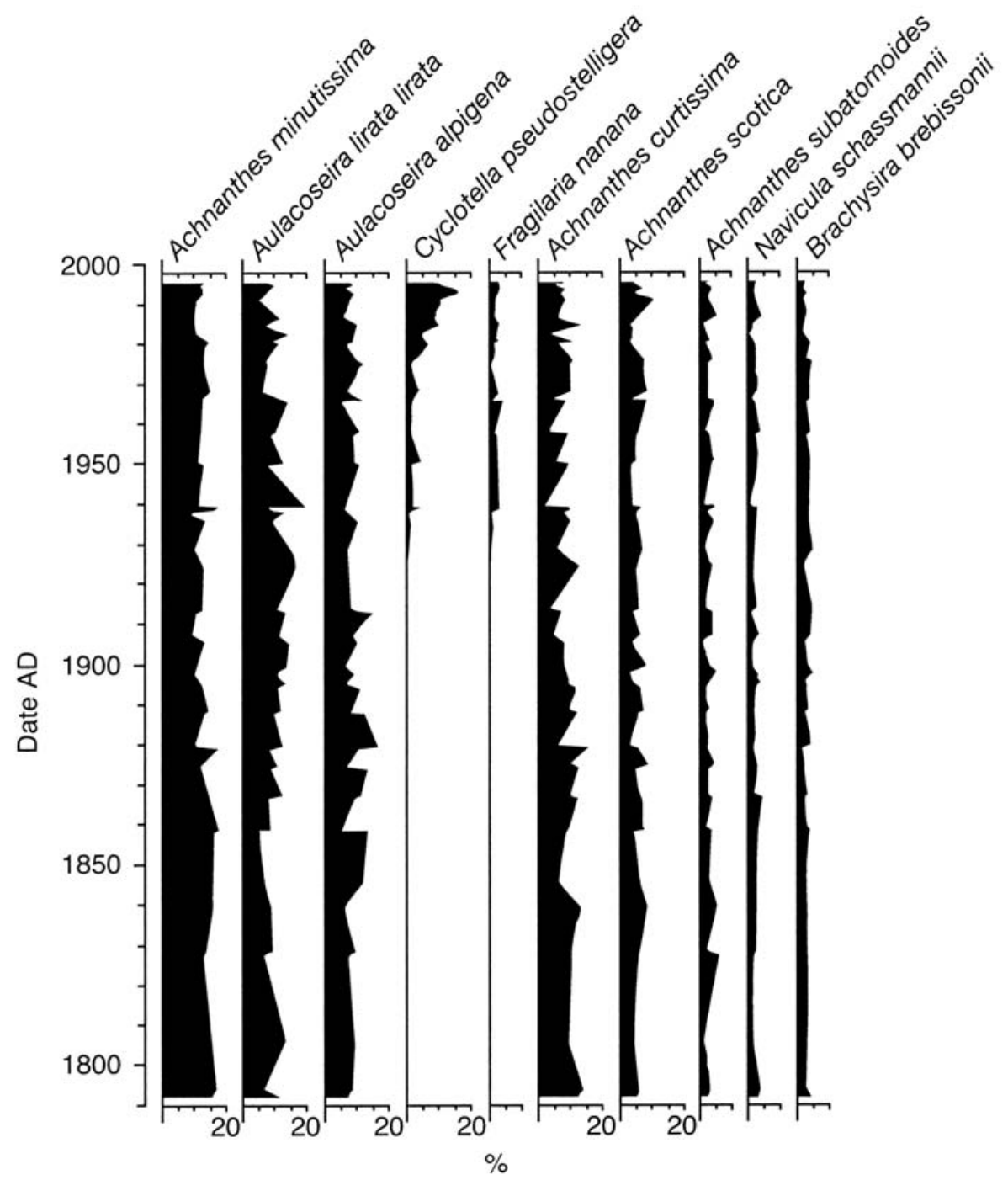

Figure 6. Diatom assemblage change from Lake Redo, Spanish Pyrenees (from Pla, 1998). Cambios en la comunidad de diatomeas en el lago Redó, Pirineos (España) (tomado de Pla, 1998). 
At other sites, recent warming appears to be having mainly an effect on primary productivity. This can be seen from both changes in diatom plankton at sites in the Pyrenees (Fig. 6) (Pla 1999, Catalan et al., 2002a), Finland (Sorvari \& Korhola 1998), Austria (Koinig et $a l ., 2002)$ and from recent increases in the amount or organic matter accumulating in sediments (Battarbee et al., 2002). These changes can best be explained as a result of changes in nutrient, especially phosphorus, loading either through water temperature and water column mixing driving internal nutrient recycling. Alternatively they may be the result of catchment change where an increase in the delivery of nutrients to the lake may be caused by reduced snow cover, enhanced carbon turnover in soils, and increased soil erosion (Catalan et al., 2002b). The specific diatom responses observed may be a combination of increased nutrient availability coupled to changes to water column stratification and mixing that favour late summer and autumn blooming taxa. In the case of Lake Redo (Figure 6), the increases in Cyclotella pseudostelligera and Fragilaria nanana are strongly related to increases in autumn air temperature (Catalan et al., 2002a).

\section{CONCLUSIONS}

Although there have been remarkable advances in the last decade, both in the study of individual sites and in attempts to up-scale our understanding to lake districts at the regional level (e.g. through the EU-EMERGE project), mountain lake ecosystems are still poorly understood. Nevertheless, in terms of human impact, recent research has shown that few if any mountain lakes are pristine, almost all are contaminated in some way by atmospherically transported pollutants, and in some cases the level of contamination is sufficiently high to have caused significant ecological change. Whilst a degree of recovery from acidification might be expected in the future there are remaining threats from toxic metals and organic compounds, and some of these threats may become greater for example if climate change causes an acceleration in the transfer of organochlorine compounds to cold regions or increased soil erosion remobilises previously buried pollutants.

Understanding how climate change influences mountain lakes both directly and indirectly by modifiying catchment processes and the behaviour of pollutants is central to future research. Emphasis needs to be placed on the interaction between acidity and climate change in different climate systems, on the transport of metals and organic compounds to lake catchments and their uptake in the lake food chain, and on the impact of climate change on biogeochemical processes that control alkalinity generation and nutrient dynamics in the lake-catchment system. Models that simulate both hydrochemical processes and biological responses need to be developed further, and, given the complexity of the potential interactions between processes, it is essential to maintain a high quality monitoring network to enable models to be tested and to serve as an early warning system for future change.

\section{ACKNOWLEDGEMENTS}

The data used in this paper have been generated through a succession of EU-funded projects between 1991 and 2003, principally: AL:PE 1: 1991-1993 Acidification of Mountain Lakes: Palaeolimnology and Ecology; AL:PE 2: 19931995 Acidification of Mountain Lakes: Palaeolimnology and Ecology; MOLAR: 19961999 Measuring and modelling the dynamic response of remote mountain lake ecosystems to environmental change, a programme of mountain lake research (http://www.natur.cuni.cz/ hydrobiology/molar/), and EMERGE: 20002003 European mountain lake ecosystems: regionalisation diagnostics \& socio-economic evaluation (http://www.mountain-lakes.org/). I am grateful to all the participants of those projects, including Hartmut Barth, our scientific officer in Brussels, for their contributions to mountain lake research, and thereby to this paper. 


\section{REFERENCES}

AGUSTÍ-PANAREDA, A. \& R. THOMPSON. 2002. Reconstructing air temperature at eleven remote alpine and arctic lakes in Europe from 1781 to 1997 AD. Journal of Paleolimnology, 28, 7-23.

BATTARBEE, R. W., N. G. CAMERON, P. GOLDING, S. J. BROOKS, R. SWITSUR, D. HARKNESS, P. G. APPLEBY, F. OLDFIELD, R. THOMPSON, D. T. MONTEITH \& A. MCGOVERN. 2001. Evidence for Holocene climate variability from the sediments of a Scottish remote mountain lake. Journal of Quaternary Science, 16, 339-346.

BATTARBEE, R. W., S. T. PATRICK, B. WATHNE, R. PSENNER \& R. MOSELLO. 2001. Measuring and modelling the dynamic response of remote mountain lake ecosystems to environmental change (the MOLAR project). Verh. Internat. Verein. Limnol., 27, 3774-3779.

BATTARBEE, R. W., J. A. GRYTNES, R. THOMPSON, P. G. APPLEBY, J. CATALAN, A. KORHOLA, H. J. B. BIRKS, E. HEEGAARD \& A. LAMI. 2002. Comparing palaeolimnological and instrumental evidence of climate change for remote mountain lakes over the last 200 years. Journal of Paleolimnology, 28, 161-179.

CATALAN, J., S. PLA, M. RIERADEVALL, M. FELIP, M. VENTURA, T. BUCHACA, L. CAMARERO, A. BRANCELJ, P. G. APPLEBY, A. LAMI, J. A. GRYTNES, A. AGUSTÍ-PANAREDA \& R. THOMPSON. 2002a. Lake Redó ecosystem response to an increasing warming the Pyrenees during the twentieth century. Journal of Paleolimnology, 28, 129-145.

CATALAN, J., M. VENTURA, A. BRANCELJ, I. GRANADOS, H. THIES, U. NICKUS, A. KORHOLA, A. F. LOTTER, A. BARBIERI, E. STUCHLÍK, L. LIEN, P. BITUŠÍK, T. BUCHACA, L. CAMARERO, G. H. GOUDSMIT, J. KOPÁCEK, G. LEMCKE, D. M. LIVINGSTONE, B. MÜLLER, M. RAUTIO, M. ŠIŠKO, S. SORVARI, F. ŠPORKA, O. STRUNECKÝ \& M. TORO. 2002b. Seasonal ecosystem variability in remote mountain lakes: implications for detecting climatic signals in sediment records. Journal of Paleolimnology, 28, $25-46$

GRIMALT, J. O., P. FERNANDEZ, L. BERDIE, R. M. VILANOVA, J. CATALAN, R. PSENNER, R. HOFER, P. G. APPLEBY, B. O. ROSSELAND, L. LIEN, J. C. MASSABUAU \& R. W. BATTARBEE. 2001. Selective trapping of organochlorine compounds in mountain lakes of temperate areas. Environmental Science and Technology, 35, 2690-2697.

JONES, V. J., R. J. FLOWER, P. G. APPLEBY, J. NATKANSKI, N. RICHARDSON, B. RIPPEY, A. C. STEVENSON \& R. W. BATTARBEE. 1993. Palaeolimnologiccal evidence for the acidification and atmospheric contamination of lochs in the Cairngorm and Lochnagar areas of Scotland. Journal of Ecology, 81, 3-24.

KOINIG, K. A., C. KAMENIK, R. SCHMIDT, A. AGUSTÍ-PANAREDA, P. G. APPLEBY, A. LAMI, M. PRAZAKOVA, N. ROSE, O.A. SCHNELL, R. TESSADRI, R. THOMPSON \& R. PSENNER. 2002. Environmental changes in an alpine lake (Gossenköllesee, Austria) over the last two centuries - the influence of air temperature on biological parameters. Journal of Paleolimnology, 28, 147-160.

PLA, S. 1999. Chrysophycean cysts from the Pyrenees and their applicability as palaeoenvironmental indicators. Phd Thesis. Univ. Barcelona

PSENNER, R. \& R. SCHMIDT. 1992. Climate-driven $\mathrm{pH}$ control of remote alpine lakes and effects of acid deposition. Nature, 356, 781-783.

ROGNERUD, S., J. O. GRIMALT, B. O. ROSSELAND, P. FERNANDEZ, R. HOFER, R. LACKNER, B. LAURITZEN, L. LIEN, J. C. MASSABUAU \& A. RIBES. 2002. Mercury and organochlorine contamination in brown trout (Salmo trutta) and arctic charr (Salvelinus alpinus) from high mountain lakes in Europe and the Svalbard archipelago. Water, Air, and Soil Pollution: Focus 2, 209-232.

ROSE, N. L., S. BACKUS, H. KARLSSON \& D. C. G. MUIR. 2001. An historical record of toxaphene and its congeners in a remote lake in Western Europe. Environmental Science \& Technology, 35, 1312-1319.

ROSE, N. L., E. SHILLAND, H. YANG, T. BERG, L. CAMARERO, R. HARRIMAN, K. KOINIG, L. LIEN, U. NICKUS, E. STUCHLIK, H. THIES \& M. VENTURA. 2002. Deposition and storage of spheroidal carbonaceious fly-ash particles in Euroepan mountain lake sediments and catchment soils. Water, Air and Soil Pollution: Focus 2, 251-260.

SOVARI, S. \& A. KORHOLA. 1998. Recent diatom assemblage changes in subarctic Lake Saanajärvi, NW Finnish Lapland, and their palaeoenvironmental implications. Journal of Paleolimnology, 20, 205-215.

YANG, H., N. L. ROSE \& R. W. BATTARBEE. 2002. Mercury and lead budgets for Lochnagar, a Scottish mountain lake and its catchment. Environmental Science and Technology, 36, 1383-1388. 